\title{
Analiza notranje strukture slovenskega prevoda Lestvice vezi med nosečnico in plodom (PAI)
}

\author{
Lucija Pavše*, Nataša Tul in Vislava Velikonja \\ Klinični oddelek za perinatologijo, Ginekološka klinika, Univerzitetni klinični center Ljubljana
}

\begin{abstract}
Povzetek: Vez med nosečnico in plodom (angl. maternal-fetal attachment) lahko opredelimo s čustvi, vedenji, zaznavami in mišljenjem, ki jih bodoča mati izraža do ploda. Različne vidike vezi med nosečnico in plodom merijo številne samoocenjevalne lestvice. Namen raziskave je bil analizirati notranjo strukturo in zanesljivost slovenskega prevoda Lestvice vezi med nosečnico in plodom (PAI, Prenatal Attachment Inventory; Müller, 1993). V raziskavo je bilo vključenih 619 nosečnic v drugem trimesečju nosečnosti, ki so imele zdravniški pregled v Porodnišnici Ljubljana, Ginekološka klinika, UKC Ljubljana. Nosečnice so izpolnile samoocenjevalno lestvico PAI ter vprašalnik o sociodemografskih spremenljivkah. Konfirmatorna faktorska analiza je pokazala nekoliko boljše prileganje trifaktorskega modela v primerjavi z enofaktorskim modelom, vendar smo se upoštevajoč visoke korelacije med tremi faktorji ter teoretično in empirično utemeljene enofaktorske rešitve iz preteklih raziskav odločili za enofaktorsko strukturo lestvice PAI. Tudi z vidika zanesljivosti je lestvica PAI ustrezen pripomoček za ocenjevanje intenzivnosti vezi med nosečnico in plodom in se lahko uporablja $\mathrm{v}$ raziskovalne namene.
\end{abstract}

Ključne besede: Lestvica vezi med nosečnico in plodom (PAI), konfirmatorna faktorska analiza, zanesljivost, sestava testa

\section{Analysis of the internal structure of the Slovenian version of the Prenatal Attachment Inventory (PAI)}

\author{
Lucija Pavše*, Nataša Tul and Vislava Velikonja \\ Division of Gynaecology and Obstetrics, University Medical Centre Ljubljana, Slovenia
}

\begin{abstract}
A phrase maternal-fetal attachment (MFA) is used to describe a variety of emotions, behaviours, perceptions and cognitions of pregnant woman toward her unborn child. Several scales have been developed for measuring different aspects of MFA. The purpose of this study was to analyse the internal structure and reliability of the Slovenian version of Prenatal Attachment Inventory (PAI; Müller, 1993). PAI and a sociodemographic questionnaire were administered to a sample of 619 pregnant women in their second trimester of pregnancy, recruited from Clinic of Gynaecology and Obstetrics in Ljubljana. Confirmatory factor analysis indicated that a three-factor solution had better fit to the data than a one-factor solution. However, we decided to keep a more parsimonious onefactor solution as there was high overlap between factors in the three-factor solution. We also considered the theoretical background of the PAI and previous studies of its underlying structure. Results showed good reliability of the PAI. PAI is a psychometrically appropriate instrument for use in research setting.
\end{abstract}

Keywords: Prenatal Attachment Inventory (PAI), confirmatory factor analysis, reliability

\footnotetext{
*Naslov/Address: Lucija Pavše, Klinični oddelek za perinatologijo, Ginekološka klinika, Univerzitetni klinični center Ljubljana, Zaloška cesta 7, 1000 Ljubljana, e-mail: lucija.vidmar@gmail.com
}

Članek je licenciran pod pogoji Creative Commons Attribution 4.0 International licence. (CC-BY licenca). The article is licensed under a Creative Commons Attribution 4.0 International License (CC-BY license). 
Koncept navezanosti med materjo in plodom (angl. maternal-fetal/antenatal/prenatal attachment) je v zadnjih 60 letih postal predmet številnih raziskav. Avtorji v raziskavah materinska čustva naklonjenosti in pripadnosti do ploda označujejo s pojmom navezanosti med materjo in plodom (Condon, 1993; Cranley, 1981; Müller, 1993), pri čemer izhajajo iz Bowlbyeve in Ainsworthove teorije navezanosti med materjo in novorojenčkom. Upoštevajoč teoretična izhodišča je izraz navezanost med nosečnico in plodom kljub pogosti uporabi v strokovni literaturi vsebinsko neustrezen (Walsh, 2010), zato Pavše, Tul Mandić in Globevnik Velikonja (2017) za označevanje vedenj, čustev, zaznav in mentalnih reprezentacij, ki jih bodoča mati izraža do nerojenega otroka, predlagajo izraz vez med nosečnico in plodom, pri čemer izhajajo iz koncepta vezi med materjo in novorojenčkom (angl. maternal bonding), ki sta ga uvedla Klaus in Kennell (1976). V nadaljevanju prispevka kljub drugačni uporabi v tuji literaturi uporabljamo zgoraj omenjeni izraz.

Kljub številnim opredelitvam pojma vezi med nosečnico in plodom ni na voljo jasne definicije tega konstrukta. Ravno tako si avtorji niso enotni glede dimenzionalnosti konstrukta. M. S. Cranley (1981) je prva omenila konstrukt vezi med nosečnico in plodom in ga definirala kot »obseg vključevanja nosečnice v vedenja, ki predstavljajo pripadnost nerojenemu otroku in interakcijo $\mathrm{z}$ njim« (str. 282). Izhajajoč iz teorije navezanosti je konstrukt razdelila na pet dimenzij: razlikovanje sebe od ploda, interakcija s plodom, pripisovanje osebnostnih značilnosti plodu, razdajanje sebe ter prevzemanje materinske vloge. Kasnejše faktorske analize lestvice Maternal-Fetal Attachment Scale (MFAS), ki jo je avtorica razvila $v$ namen merjenja vezi med nosečnico in plodom, večfaktorske strukture niso potrdile (Müller in Ferketich, 1993). Condon je pri sestavi lestvice Maternal Antenatal Attachment Scale (MAAS; Condon, 1993) ravno tako izhajal iz teorije navezanosti, s faktorsko analizo pa potrdil dvodimenzionalnost lestvice (kvaliteta odnosa med nosečnico in plodom, intenzivnost preokupacije s plodom).

Samoocenjevalne lestvice, s katerimi merimo izraženost vezi med nosečnico in plodom, temeljijo na predpostavki, da se vez med bodočo materjo in njenim nerojenim otrokom kaže prek čustev (ljubezen in naklonjenost do nerojenega otroka), misli (predstave o zunanjem videzu in osebnostnih lastnosti otroka, izbiranje imena) in vedenj (skrb za zdrav življenjski slog nosečnice, pomirjanje ploda prek božanja trebuha, govorjenje plodu, priprava pripomočkov za novorojenčka, pogovarjanje s partnerjem o otroku in prihodnosti, pridobivanje informacij o razvijajočem otroku), s katerimi nosečnica izraža nego in predanost plodu (Condon, 1993; Cranley, 1981, Hart in McMahon, 2006; Salisbury, 2003). Avtorji lestvic predpostavljajo, da se ženska teh čustev, misli in vedenja zaveda ter posledično lahko poroča o njihovi pogostosti pojavljanja (Van den Bergh in Simons, 2009). Izraženost vezi med nosečnico in plodom merijo lestvice Maternal-Fetal Attachment Scale (MFAS; Cranley, 1981), Maternal Antenatal Attachment Scale (MAAS; Condon, 1993), Prenatal Attachment Inventory (PAI; Müller, 1993), Modified Maternal Foetal Attachment Scale (MMFA; Hsu in Chen, 2001), Prenatal Tool (Rees, 1980), Antenatal Maternal Attachment Scale (AMAS; Honjo idr., 2003), Pregnancy Involvement List (PIL, Kleinveld, Timmermans, Van den
Berg, Van Eijk in Ten Kate, 2007) in Pictorial Representation of Attachment Measure (PRAM; Van Bakel, Maas, Vreeswijk in Vingerhoets, 2013).

$\mathrm{V}$ naši raziskavi smo uporabili samoocenjevalno lestvico Prenatal Attachment Inventory (PAI; Müller, 1993). Müller (1993) je vez med nosečnico in plodom definirala kot edinstven ljubeč odnos med bodočo materjo in njenim nerojenim otrokom. Avtorica je pri sestavi lestvice izhajala iz teoretičnega modela navezanosti (Bowlby, 1982), ki predpostavlja, da so začetne izkušnje navezanosti podlaga za razvoj notranjih reprezentacij, na podlagi katerih posameznik kasneje razvije navezanost $\mathrm{s}$ pomembnimi osebami. Pri vsebinski sestavi postavk je izhajala tudi iz predpostavke, da je proces prilagajanja ženske na nosečnost, proces prevzemanja materinske vloge ter stil navezanosti ženske povezan z razvojem vezi med nosečnico in njenim nerojenim otrokom. Prvotnih 48 postavk je pregledalo 11 različnih teoretikov, medicinske sestre, ki izvajajo perinatalno nego, in nosečnice. Na podlagi analize glavnih komponent na vzorcu 310 nosečnic je avtorica poročala o enofaktorski strukturi lestvice. $\mathrm{Na}$ podlagi vsebinskega pregleda enofaktorske rešitve, ki je zajemala izražanje naklonjenosti plodu, interakcijo s plodom, sanjarjenje o plodu in pripravljanje na prihod novorojenčka je avtorica zaključila, da lestvica PAI ustrezno predstavlja celoten pojem vezi med nosečnico in plodom. Po izločitvi neustreznih postavk končno verzijo lestvice predstavlja 21 postavk. Kot dobra se je izkazala sočasna veljavnost lestvice (koeficient korelacije z lestvico MFAS, ki meri izraženost vezi med nosečnico in plodom, $r=$ $0,72, p<0,01$ ), ter konstruktna veljavnost lestvice (koeficient korelacije $\mathrm{z}$ lestvico, ki meri stopnjo prilagojenosti ženske na nosečnost, $r=0,25, p<0,01)$.

Enofaktorsko strukturo lestvice sta na vzorcu 349 nosečnic s konfirmatorno faktorsko analizo potrdila Gau in Lee (2003), pri čemer so indeksi prileganja kazali na slabše, a še zadovoljivo prileganje modela podatkom $\left(\mathrm{GFI}=0,90, \chi^{2} / d f\right.$ $=2,12$ ). Cronbachov koeficient zanesljivosti $\alpha$ je znašal 0,89 .

Pallant, Haines, Hildingsson, Cross in Rubertsson (2014) so izvedli podrobno analizo konstruktne veljavnosti lestvice PAI na vzorcu 775 žensk. Na podlagi paralelne analize in grafa drobirja so ugotovili, da je najbolj smiselna trifaktorska ali enofaktorska rešitev. Najboljše prileganje podatkom je imela trifaktorska rešitev (RMSEA $=0,06, \mathrm{CFI}=0,90$, GFI $=0,91)$. Prvi faktor so avtorji poimenovali Pričakovanje $(\alpha=$ $0,78)$, drugega Diferenciacija $(\alpha=0,73)$ in tretjega Interakcija $(\alpha=0,78)$.

Drugi avtorji pa so poročali o petfaktorski strukturi lestvice PAI. Na Švedskem so Siddiqui, Hägglöf in Eisemann (1999) identificirali petfaktorsko strukturo, ki je pojasnila 53,9 \% skupne variance. Prvi faktor so poimenovali Fantaziranje $(\alpha=0,76)$, drugi Interakcija $(\alpha=0,69)$, tretji Naklonjenost $(\alpha$ $=0,66)$, četrti Diferenciacija sebe od ploda $(\alpha=0,62)$, peti faktor pa Deljenje z drugimi $(\alpha=0,57)$. Cronbachov koeficient zanesljivosti $\alpha$ za celotno lestvico PAI je znašal 0,86 . Kljub ugotovljeni petfaktorski strukturi sta avtorja zaključila, da je vez med nosečnico in plodom sicer konstrukt več dimenzij, ki pa med seboj niso neodvisne, temveč povezane.

Bielawska-Batorowicz in Siddiqui (2008) sta na vzorcu švedskih in poljskih nosečnic na podlagi analize glavnih komponent ugotovila petfaktorsko strukturo lestvice PAI: 
Fantaziranje, Interakcija, Deljenje, Pripisovanje lastnosti in Naklonjenost. Cronbachov koeficient zanesljivosti $\alpha$ za celotno lestvico PAI je na vzorcu švedskih nosečnic znašal 0,86 , na vzorcu poljskih nosečnic pa 0,85 .

$\mathrm{Na}$ vzorcu 250 italijanskih nosečnic so Della Vedova, Dabrassi in Imbasciati (2008) na podlagi eksploratorne faktorske analize ravno tako poročali o petfaktorski strukturi lestvice PAI, ki je pojasnila 41,23 \% skupne variance. Vsebinsko so se ugotovljeni faktorji skoraj v celoti ujemali s faktorji, ki jih je identificiral Siddiqui s sodelavci (1999). Kljub temu so avtorji zaključili, da je veljavnost in zanesljivost lestvice PAI boljša, če za merjenje intenzivnosti vezi med nosečnico in plodom upoštevamo skupni dosežek na celotni lestvici in ne na posameznih podlestvicah. Cronbachov koeficient zanesljivosti $\alpha$ za celotno lestvico PAI je znašal 0,87 .

Barone, Lionetti in Dellagiulia (2014) so na podlagi analize glavnih komponent ugotovili petfaktorsko strukturo lestvice PAI, ki je pojasnila 59,44\% variance. Faktorje so poimenovali: Naklonjenost $(\alpha=0,78)$, Interakcija $(\alpha=0,81)$, Diferenciacija nosečnice od ploda $(\alpha=0,63)$, Fantaziranje ( $\alpha$ $=0,59)$, Rahločutnost $(\alpha=0,47)$.

Nobeden od zgoraj omenjenih avtorjev, ki so poročali o petfaktorski strukturi lestvice PAI, ni izvedel konfirmatorne faktorske analize, zato prileganje petfaktorskega modela podatkom ni znano. Ravno tako ti avtorji niso preverjali sočasne in kriterijske veljavnosti lestvice. Vsebinski pregled ugotovljenih faktorjev pokaže, da omenjeni faktorji zajemajo vse vidike konstrukta vezi med nosečnico - čustva, misli in vedenja, ki jih nosečnica izraža do ploda.

Pregled preteklih raziskav o analizi notranje strukture lestvice PAI kaže, da faktorska struktura lestvice ni povsem jasna, zato je bil namen naše raziskave analizirati notranjo strukturo in zanesljivost slovenskega prevoda Lestvice vezi med nosečnico in plodom (PAI). Če upoštevamo teoretična izhodišča, iz katerih so pri opredelitvi pojma vezi med nosečnico in plodom izhajali različni avtorji, lahko govorimo o enodimenzionalnem (Müller, 1993) ali večdimenzionalnem konstruktu (Condon, 1993; Cranley, 1981). Z vidika prileganja modela podatkom sta se $\mathrm{v}$ preteklih raziskavah kot ustrezni izkazali tako enofaktorska (Gau in Lee, 2003) kot tudi trifaktorska struktura (Pallant idr., 2014) lestvice PAI. Zato smo se odločili, da z izvedbo konfirmatorne faktorske analize preverimo prileganje enofaktorskega in trifaktorskega modela podatkom. Prileganja petfaktorskega modela podatkom nismo preverjali, saj avtorji, ki so poročali o petfaktorski strukturi lestvice PAI (Barone idr., 2014; Bielawska-Batorowicz in Siddiqui, 2008; Della Vedova idr., 2008; Siddiqui idr., 1999), niso izvedli konfirmatorne faktorske analize, zato prileganje petfaktorskega modela podatkom ni znano.

\section{Metoda}

\section{Udeleženci}

V raziskavi je sodelovalo 619 nosečnic, od tega je bilo 445 nosečih z enim plodom (71,9\%), 174 pa z dvema plodoma $(28,1 \%)$. V povprečju so bile nosečnice stare 31,8 let $(S D$ $=4,7)$ in $\mathrm{v} 21,9$. tednu nosečnosti $(S D=1,7)$. $\mathrm{V}$ tabeli 1 so predstavljeni demografski in socialno-ekonomski podatki za nosečnice $\mathrm{z}$ enojčkom in za nosečnice $\mathrm{z}$ dvojčkoma.

Zbiranje podatkov je potekalo med januarjem 2015 in januarjem 2017. Vključitveni kriteriji so bili polnoletnost (starost nad 18 let), razumevanje slovenskega jezika ter višina nosečnosti med 13. in 34. tednom. Dvajset nosečnic je povabilo k sodelovanju v raziskavi zavrnilo (97-odstotna odzivnost). Osem udeleženk smo izključili naknadno zaradi neujemanja $\mathrm{z}$ vključitvenimi kriteriji, končni vzorec je tako znašal 619 nosečnic.

\section{Pripomočki}

Lestvica vezimednosečnicoin plodom. Samoocenjevalna lestvica PAI (Müller, 1993) meri intenzivnost čustev, misli in vedenj, ki jih nosečnica izraža do ploda. Lestvico sestavlja 21 postavk, pri katerih mora posameznica na 4-stopenjski lestvici $(1=$ skoraj nikoli, $2=$ včasih, $3=$ pogosto, $4=$ skoraj vedno) označiti, kako pogosto se je posamezna misel/čustvo/ vedenje pojavilo v zadnjih dveh tednih. Višji rezultat označuje višjo stopnjo izraženosti vezi med nosečnico in plodom (maksimalni dosežek je 84, minimalni dosežek pa 21).

\section{Postopek}

Lestvico PAI, ki je dostopna v prispevku avtorice lestvice (Müller, 1993), smo $\mathrm{z}$ dovoljenjem avtorice prevedli in priredili za uporabo na slovenskem vzorcu. Lestvico smo iz izvirnega angleškega jezika najprej prevedli v slovenščino, prevod v slovenščino je neodvisno opravila tudi anglistka. Slovenska prevoda smo med seboj primerjali z vidika njune vsebine, pravopisne in skladenjske ustreznosti ter ju uskladili. Slovenski prevod lestvice je druga anglistka brez poznavanja izvirnika $\mathrm{v}$ angleškem jeziku prevedla $\mathrm{v}$ angleščino. Obe različici slovenskega prevoda lestvice (izvirno in vzvratno prevedeno) smo med seboj primerjali z vidika njune vsebine, pravopisne in skladenjske ustreznosti ter ju uskladili. Slovenski prevod lestvice PAI je v Prilogi.

$\mathrm{K}$ sodelovanju $\mathrm{v}$ raziskavi so bile povabljene nosečnice med 13. in 34. tednom nosečnosti, ki so imele zdravniški pregled pri izbranem ginekologu v Porodnišnici Ljubljana, Ginekološka klinika, UKC Ljubljana. Udeleženkam smo predstavili raziskavo, njen namen, zagotovili anonimnost ter jih povabili $\mathrm{k}$ sodelovanju. Tiste, ki so se odločile za sodelovanje, smo prosili za elektronski naslov, na katerega smo jim $\mathrm{v}$ elektronski obliki poslali sklop vprašalnikov (Lestvica vezi med nosečnico in plodom PAI ter vprašalnik o demografskih in socialno-ekonomskih spremenljivkah). Osebni podatki udeleženk so bili varovani v skladu z Zakonom o varovanju osebnih podatkov. Raziskavo je odobrila Komisija Republike Slovenije za medicinsko etiko (št. 68/10/14).

\section{Analiza podatkov}

Konfirmatorno faktorsko analizo smo izvedli s programom LISREL 8.8 (Jöreskog in Sörbom, 2006). Prileganje modela smo ocenili s $\chi^{2}$ statistiko in indeksi prileganja. Pri izbiri indeksov in pristopu $\mathrm{k}$ evalvaciji modela smo sledili priporočilom Browna (2015). Za določanje ustreznosti 
Tabela 1. Demografski in socialno-ekonomski podatki za nosečnice z enojčkom in nosečnice z dvojčkoma

\begin{tabular}{|c|c|c|}
\hline Spremenljivka & Enojček & Dvojčka \\
\hline \multicolumn{3}{|l|}{ Stopnja izobrazbe $[f(\%)]$} \\
\hline Nepopolna osnovnošolska & $1(0,2 \%)$ & $0(0 \%)$ \\
\hline Osnovnošolska & $3(0,7 \%)$ & $4(2,3 \%)$ \\
\hline Poklicna & $85(19,1 \%)$ & $37(21,3 \%)$ \\
\hline Gimnazija & $44(9,9 \%)$ & $15(8,6 \%)$ \\
\hline Višješolska/visokošolska (1. bolonjska stopnja) & $122(27,5 \%)$ & $52(29,9 \%)$ \\
\hline Univerzitetna (2. bolonjska stopnja) & $158(35,6 \%)$ & $53(30,5 \%)$ \\
\hline Magisterij znanosti (po starem sistemu) & $22(5 \%)$ & $9(5,2 \%)$ \\
\hline Doktorat znanosti (3. bolonjska stopnja) & $9(2 \%)$ & $4(2,3 \%)$ \\
\hline \multicolumn{3}{|l|}{ Zakonski stan $[f(\%)]$} \\
\hline Izvenzakonska skupnost & $276(62 \%)$ & $103(59,2 \%)$ \\
\hline Poročena & $169(38 \%)$ & $71(40,8 \%)$ \\
\hline \multicolumn{3}{|l|}{ Ocena mesečnega dohodka $[f(\%)]$} \\
\hline Podpovprečni & $50(12 \%)$ & $20(12,1 \%)$ \\
\hline Povprečni & $302(72,1 \%)$ & $123(74,5 \%)$ \\
\hline Nadpovprečni & $67(16 \%)$ & $22(13,3 \%)$ \\
\hline \multicolumn{3}{|l|}{ Zaposlitev $[f(\%)]$} \\
\hline $\mathrm{Da}$ & $363(81,6 \%)$ & $143(82,2 \%)$ \\
\hline $\mathrm{Ne}$ & $29(6,5 \%)$ & $6(3,4 \%)$ \\
\hline Dijak/študent & $53(11,9 \%)$ & $25(14,4 \%)$ \\
\hline \multicolumn{3}{|l|}{ Zaposlitev po porodniški $[f(\%)]$} \\
\hline $\mathrm{Da}$ & $310(69,7 \%)$ & $118(67,8 \%)$ \\
\hline $\mathrm{Ne}$ & $135(30,3 \%)$ & $56(32,2 \%)$ \\
\hline
\end{tabular}

Opombe. Odstotki pri spremenljivkah z več kategorijami so računani znotraj posamezne spremenljivke za nosečnice z enojčkom in nosečnice z dvojčki posebej.

prileganja modelov smo uporabili kriterije, priporočene $\mathrm{v}$ simulacijski študiji Hu in Bentlerja (1999): RMSEA < 0,06, CFI $>0,95$, TLI $>0,95$, SRMR $<0,08$. Kot še sprejemljivo prileganje modela smo upoštevali tudi vrednosti indeksov blizu priporočenim (npr. RMSEA < 0,08). Opisne statistike in zanesljivosti lestvice smo izračunali s programom SPSS 21.0. Manjkajoče vrednosti se niso pojavljale.

\section{Rezultati}

V tabeli 2 so prikazane opisne statistike ter frekvence izbir posameznih kategorij za posamezne postavke lestvice PAI.

\section{Analiza notranje strukture}

$\mathrm{Na}$ podlagi preteklih raziskav smo s konfirmatorno faktorsko analizo preverili prileganje enofaktorske in trifaktorske rešitve. Trifaktorski model smo specificirali na isti način kot je to v svoji raziskavi na podlagi konfirmatorne faktorske analize storila Pallant s sodelavci (2014), in sicer smo postavke razdelili v naslednje faktorje: Pričakovanje, Diferenciacija, Interakcija.
Postavke so bile merjene na 4-stopenjski lestvici, ki ustreza ordinalni merski ravni, zato smo kot metodo ocenjevanja parametrov uporabili metodo diagonalno obteženih najmanjših kvadratov (DWLS) s polihoričnimi korelacijami in asimptotično kovariančno matriko kot vhodnimi podatki. $\mathrm{V}$ tabeli 3 so prikazani $\chi^{2}$ test in indeksi prileganja za enofaktorski in trifaktorski model. Ugotovili smo, da oba modela statistično pomembno odstopata od vhodnih podatkov. Upoštevati moramo, da je $\chi^{2}$ pri večjem vzorcu občutljiv tudi na trivialna odstopanja med vhodnimi in reproduciranimi podatki (Brown, 2015), zato smo v nadaljevanju pregledali indekse prileganja. Indeksi prileganja kažejo, da se oba modela mejno sprejemljivo prilegata podatkom. Absolutni indeks prileganja SRMR kaže, da lahko z modeloma ustrezno pojasnimo vhodne povezanosti (kovariance) med postavkami. Primerjalni indeksi (CFI, TLI) kažejo na odlično prileganje modelov v primerjavi z ničelnim modelom. Parsimonični indeks RMSEA je pri obeh modelih višji od vrednosti 0,06 , kar kaže na nekoliko slabše prileganje modelov.

Za enofaktorsko in trifaktorsko rešitev smo v nadaljevanju pregledali modifikacijske indekse. Pallant je s sodelavci (2014) V svoji trifaktorski rešitvi dopustila povezanost napak postavk $15 / 18$ in $10 / 11$ ter povezanost utemeljila $\mathrm{s}$ teoretičnega vidika. Tako postavka 15 (Rada sedim tako, 
Tabela 2. Opisne statistike ter frekvence izbir posameznih kategorij za postavke lestvice PAI

\begin{tabular}{|c|c|c|c|c|c|c|}
\hline \multirow[b]{2}{*}{ Postavka } & \multirow[b]{2}{*}{$M$} & \multirow[b]{2}{*}{$S D$} & \multicolumn{4}{|c|}{$f[\%]$} \\
\hline & & & Skoraj nikoli & Včasih & Pogosto & Skoraj vedno \\
\hline PAI 1 & 2,09 & 1,07 & $238(38,4 \%)$ & $181(29,2 \%)$ & $108(17,4 \%)$ & $92(14,9 \%)$ \\
\hline PAI 2 & 2,54 & 0,94 & $87(14,1 \%)$ & $220(35,5 \%)$ & $201(32,5 \%)$ & $111(17,9 \%)$ \\
\hline PAI 3 & 3,75 & 0,60 & $12(1,9 \%)$ & $17(2,7 \%)$ & $87(14,1 \%)$ & $503(81,3 \%)$ \\
\hline PAI 4 & 2,66 & 1,12 & $120(19,4 \%)$ & $169(27,3 \%)$ & $133(21,5 \%)$ & $197(31,8 \%)$ \\
\hline PAI 5 & 2,97 & 1,08 & $76(12,3 \%)$ & $142(22,9 \%)$ & $123(19,9 \%)$ & $278(44,9 \%)$ \\
\hline PAI 6 & 3,32 & 0,78 & $14(2,3 \%)$ & $77(12,4 \%)$ & $222(35,9 \%)$ & $306(49,4 \%)$ \\
\hline PAI 7 & 2,53 & 1,00 & $105(17 \%)$ & $207(33,4 \%)$ & $179(28,9 \%)$ & $128(20,7 \%)$ \\
\hline PAI 8 & 2,33 & 0,96 & $129(20,8 \%)$ & $246(39,7 \%)$ & $155(25 \%)$ & $89(14,4 \%)$ \\
\hline PAI 9 & 1,88 & 0,93 & $267(43,1 \%)$ & $201(32,5 \%)$ & $110(17,8 \%)$ & $41(6,6 \%)$ \\
\hline PAI 10 & 2,39 & 1,02 & $145(23,4 \%)$ & $187(30,2 \%)$ & $185(29,9 \%)$ & $102(16,5 \%)$ \\
\hline PAI 11 & 1,95 & 0,88 & $214(34,6 \%)$ & $269(43,5 \%)$ & $92(14,9 \%)$ & $44(7,1 \%)$ \\
\hline PAI 12 & 3,87 & 0,41 & $1(0,2 \%)$ & $13(2,1 \%)$ & $52(8,4 \%)$ & $553(89,3 \%)$ \\
\hline PAI 13 & 2,30 & 1,07 & $171(27,6 \%)$ & $211(34,1 \%)$ & $119(19,2 \%)$ & $118(19,1 \%)$ \\
\hline PAI 14 & 2,69 & 0,92 & $62(10 \%)$ & $203(32,8 \%)$ & $221(35,7 \%)$ & $133(21,5 \%)$ \\
\hline PAI 15 & 3,15 & 0,87 & $29(4,7 \%)$ & $105(17 \%)$ & $227(36,7 \%)$ & $258(41,7 \%)$ \\
\hline PAI 16 & 2,00 & 0,97 & $226(36,5 \%)$ & $227(36,7 \%)$ & $104(16,8 \%)$ & $62(10 \%)$ \\
\hline PAI 17 & 2,30 & 0,99 & $148(23,9 \%)$ & $231(37,3 \%)$ & $148(23,9 \%)$ & $92(14,9 \%)$ \\
\hline PAI 18 & 3,37 & 0,78 & $14(2,3 \%)$ & $72(11,6 \%)$ & $207(33,4 \%)$ & $326(52,7 \%)$ \\
\hline PAI 19 & 1,86 & 1,00 & $291(47 \%)$ & $184(29,7 \%)$ & $81(13,1 \%)$ & $63(10,2 \%)$ \\
\hline PAI 20 & 3,26 & 0,90 & $34(5,5 \%)$ & $88(14,2 \%)$ & $180(29,1 \%)$ & $317(51,2 \%)$ \\
\hline PAI 21 & 3,31 & 0,83 & $23(3,7 \%)$ & $80(12,9 \%)$ & $200(32,3 \%)$ & $316(51,1 \%)$ \\
\hline
\end{tabular}

Opombe. Postavke slovenske različice lestvice PAI se nahajajo v prilogi.

da z rokami objemam trebuh.) kot tudi postavka 18 (Otroka božam preko trebuha.) opisujeta dotikanje trebuha. Postavka 10 (Vem, kdaj moj otrok spi.) in postavka 11 (Svojega otroka lahko pripravim do premikanja.) se nanašata na gibanje otroka. Za naš enofaktorski in trifaktorski model smo prav tako po korakih odkrili zelo visoka modifikacijska indeksa za povezanost napak parov postavk $15 / 18$ in $10 / 11$. Strinjali smo se z vsebinskimi argumenti, ki jih je v študiji navedla Pallant s sodelavci (2014) ter dopustili povezanost napak med posameznim parom postavk. Omenjena para postavk si verjetno delita specifičen del variabilnosti, ki ni del konstrukta vezi med nosečnico in plodom. Pallant je s sodelavci (2014) v svoji študiji dopustila povezanost napak tudi med postavkama 3 (Prijetno mi je, ko čutim otrokovo premikanje.) in 12 (Do otroka čutim ljubezen.). Avtorica je dopustnost povezanosti napak med postavkama argumentirala s pojasnilom, da obe postavki merita čustva nosečnice do nerojenega otroka. Ker čustva nosečnice do ploda merita tudi postavki 21 in 12 , čustva pa so tudi sestavni del konstrukta vezi med nosečnico in plodom (Condon, 1993; Müller, 1993), v našem modelu nismo dopustili povezanosti napak postavk 3 in 12. Smo pa v našem modelu (tako enofaktorskem kot tudi trifaktorskem) odkrili visok modifikacijski indeks za povezanost napak postavk 21 (Ko pomislim na otroka, me

Tabela 3. Indeksi prileganja za enofaktorski in trifaktorski model

\begin{tabular}{llrrrrrr}
\hline & S-B $\chi^{2}$ & $d f$ & CFI & TLI & RMSEA & SRMR & AIC \\
\hline Enofaktorski model & $815,7^{*}$ & 189 & 0,958 & 0,953 & 0,073 & 0,075 & 899,7 \\
Trifaktorski model & $754,0^{*}$ & 186 & 0,962 & 0,957 & 0,070 & 0,071 & 844,0 \\
Modificiran enofaktorski model $^{\mathrm{a}}$ & $644,0^{*}$ & 186 & 0,969 & 0,965 & 0,063 & 0,068 & 734,0 \\
Modificiran trifaktorski model $^{\mathrm{a}}$ & $608,2^{*}$ & 183 & 0,971 & 0,967 & 0,061 & 0,066 & 704,2 \\
\hline
\end{tabular}

Opombe: S-B $\chi^{2}=$ Satorra-Bentler $\chi^{2}, d f=$ prostostne stopnje, RMSEA $=$ root mean square error of approximation, TLI $=$ Tucker-Lewis index, $\mathrm{CFI}=$ comparative fit index, $\mathrm{SRMR}=$ standardized root mean square residual, $\mathrm{AIC}=$ Akaike information criterion.

$N=619$.

${ }^{a}$ dovoljena korelacija med napakami parov postavk $15 / 18,10 / 11$ in 21/12.

${ }^{*} p<0,001$. 
prevzamejo močna čustva.) in 12 (Do otroka čutim ljubezen.). To sta edini postavki v lestvici PAI, ki eksplicitno merita čustva nosečnice do nerojenega otroka. Povezanost napak teh dveh postavk smo dopustili, saj obe postavki eksplicitno merita čustva nosečnice do nerojenega otroka. Menimo, da sta obe postavki občutljivi na socialno zaželeno odgovarjanje (za razliko od ostalih postavk, ki so bolj implicitne narave) in si tako delita specifičen del variabilnosti, ki ni del konstrukta vezi med nosečnico in plodom.

$\mathrm{Z}$ omenjenimi spremembami se je prileganje modela podatkom nekoliko izboljšalo (tabela 3). Modificiran enofaktorski in trifaktorski model se glede na indekse prileganja zadovoljivo prilegata podatkom. Indeksi prileganja so malenkost boljši od tistih, ki jih je v svoji raziskavi ugotovila Pallant s sodelavci (2014). Nadalje lahko opazimo, da se enofaktorski in trifaktorski model v indeksih prileganja bistveno ne razlikujeta. Nižja vrednost AIC kaže, da je trifaktorski model sicer nekoliko ustreznejši od enofaktorskega.

Pri izbiri končnega modela nismo upoštevali zgolj indeksov prileganja, saj so si ti po velikosti pri obeh modelih zelo podobni. Pomemben kriterij pri izbiri ustreznega modela je tudi parsimoničnost modela (Brown, 2015). V modificiranem trifaktorskem modelu smo ugotovili zelo visoke korelacije med faktorji. Korelacija med faktorjema Pričakovanje in Diferenciacija je znašala 0,84, med Pričakovanjem in Interakcijo 0,92, med Diferenciacijo in Interakcijo pa 0,87 . Zavoljo večje parsimoničnosti modela $\mathrm{z}$ minimalnim poslabšanjem prileganja modela podatkom smo se zato odločili, da obdržimo enofaktorski model. Prednost parsimoničnih modelov je ta, da imajo manj konkurenčnih (ekvivalentnih) modelov, so bolj robustni in lažje ponovljivi.

V nadaljevanju smo izračunali standardizirane faktorske uteži in pripadajoče komunalitete za izbran modificiran enofaktorski model, ki so prikazane v tabeli 4. Korelacije med napakami znašajo za postavki 10 in $11 r=0,31, S E=0,035$, za postavki 15 in $18 r=0,23, S E=0,034$, za postavki 12 in 21 $r=0,26, S E=0,045$. Vse uteži so statistično pomembne ( $p$ $<0,001)$. Faktorske uteži so po velikosti zadovoljivo visoke, zato smo obdržali vse postavke.

Povprečen rezultat na skupnem dosežku na lestvici PAI je znašal 56,52 $(S E=0,42, S D=10,42)$, mediana pa $56,40\left(\mathrm{Q}_{3}-\right.$ $\left.\mathrm{Q}_{1}=14,02\right)$. Skupni dosežek na lestvici PAI je porazdeljen približno normalno $\left(A s=0,030, S E_{\mathrm{As}}=0,098, S p l=-0,341\right.$, $\left.S E_{\mathrm{Spl}}=0,196\right)$.

\section{Zanesljivost}

Zanesljivost lestvice PAI, izračunana s Cronbachovim koeficientom $\alpha$, je znašala 0,877 . Čeprav Cronbachov koeficient $\alpha$ ponuja hitro oceno zanesljivosti, pa predpostavlja, da so postavke esencialno $\tau$-ekvivalentne. Kršenje predpostavk se kaže v nižji oceni zanesljivosti, zaradi česar predstavlja $\alpha$ spodnjo mejo zanesljivosti (Sočan, 2011). Glede na raznolikost uteži znotraj vsake lestvice (tabela 4) smo predvideli, da je bila v našem primeru kršena predpostavka $\tau$-ekvivalentnosti, zato smo izračunali koeficient zanesljivosti, ki ga predlaga Raykov (2004). Prednost omenjenega koeficienta je tudi v tem, da lahko upoštevamo korelacijo napak. Ugotovili smo zelo visoko zanesljivost, ocenjeno s postopkom Raykova, $\rho$ $=0,902$.
Tabela 4. Standardizirane faktorske uteži, komunalitete in standardne napake za modificiran enofaktorski model lestvice PAI

\begin{tabular}{|c|c|c|c|}
\hline Postavka & $\lambda$ & $S E$ & $h^{2}$ \\
\hline PAI 1 & 0,48 & 0,04 & 0,230 \\
\hline PAI 2 & 0,54 & 0,04 & 0,295 \\
\hline PAI 3 & 0,46 & 0,06 & 0,207 \\
\hline PAI 4 & 0,61 & 0,03 & 0,371 \\
\hline PAI 5 & 0,39 & 0,05 & 0,152 \\
\hline PAI 6 & 0,50 & 0,04 & 0,245 \\
\hline PAI 7 & 0,60 & 0,03 & 0,363 \\
\hline PAI 8 & 0,67 & 0,03 & 0,449 \\
\hline PAI 9 & 0,63 & 0,03 & 0,392 \\
\hline PAI 10 & 0,48 & 0,04 & 0,232 \\
\hline PAI 11 & 0,48 & 0,04 & 0,229 \\
\hline PAI 12 & 0,52 & 0,06 & 0,274 \\
\hline PAI 13 & 0,54 & 0,04 & 0,296 \\
\hline PAI 14 & 0,76 & 0,03 & 0,576 \\
\hline PAI 15 & 0,66 & 0,03 & 0,432 \\
\hline PAI 16 & 0,59 & 0,04 & 0,349 \\
\hline PAI 17 & 0,56 & 0,04 & 0,309 \\
\hline PAI 18 & 0,67 & 0,03 & 0,449 \\
\hline PAI 19 & 0,70 & 0,03 & 0,490 \\
\hline PAI 20 & 0,57 & 0,04 & 0,320 \\
\hline PAI 21 & 0,58 & 0,04 & 0,341 \\
\hline
\end{tabular}

Opombe: $\lambda=$ standardizirana faktorska utež, $S E=$ standardna napaka, $h^{2}=$ komunaliteta

\section{Razprava}

$\mathrm{V}$ raziskavi smo analizirali notranjo strukturo slovenskega prevoda Lestvice vezi med nosečnico in plodom (PAI; Müller, 1993). Z izvedbo konfirmatorne faktorske analize smo preverili prileganje enofaktorskega in trifaktorskega modela podatkom. Ugotovitve naše raziskave so potrdile ugotovitve avtorjev, ki so na podlagi konfirmatorne faktorske analize poročali o trifaktorski strukturi lestvice PAI (Pallant idr., 2014), saj se je v naši raziskavi trifaktorski model nekoliko bolje prilegal podatkom kot enofaktorski model. Ker pa so si bili indeksi prileganja pri obeh modelih zelo podobni in ker je $\mathrm{v}$ modificiranem trifaktorskem modelu prihajalo do visokih korelacij med faktorji, smo se odločili za izbor enofaktorske strukture lestvice PAI. Tudi Brown (2015) v primeru visokega prekrivanja med faktorji $\mathrm{v}$ večfaktorskem modelu kljub slabšemu prileganju enofaktorskega modela predlaga, da se zavoljo večje parsimoničnosti obdrži enofaktorsko rešitev. Pri odločitvi za izbor enofaktorske rešitve smo upoštevali tudi teoretična izhodišča avtorice lestvice PAI (Müller, 1993), ki je vez med nosečnico in plodom definirala kot edinstven ljubeč odnos med bodočo materjo in njenim nerojenim otrokom, ki zajema interakcijo nosečnice s plodom, izražanje naklonjenosti do ploda, sanjarjenje o plodu ter pripravljenost na prihod novorojenčka. Vsebinski pregled trifaktorske rešitve 
je pokazal, da omenjeni faktorji zajemajo vse prej omenjene vidike konstrukta vezi med nosečnico (interakcija nosečnice s plodom, ki se kaže prek izražanja naklonjenosti plodu in dotikanja trebuha, ter pričakovanje novorojenčka, ki se kaže prek načrtovanja aktivnosti z njim in prek predstav o njegovem videzu ter osebnostnih lastnosti). Zaradi teh ugotovitev je tudi s teoretičnega vidika enofaktorska rešitev ustreznejša. Naša odločitev za izbor enofaktorske strukture lestvice PAI je skladna tudi z ugotovitvami pretekle raziskave (Gau in Lee, 2003), v kateri sta avtorja s pomočjo konfirmatorne faktorske analize potrdila enofaktorsko strukturo lestvice PAI. Z vidika zanesljivosti je lestvica PAI ustrezna za merjenje intenzivnosti vezi med nosečnico in plodom.

Nadaljnje raziskovanje notranje strukture lestvice PAI je potrebno razširiti na bolj heterogen vzorec nosečnic. V naši raziskavi je bila namreč večina nosečnic prvorodk $\mathrm{z}$ višješolsko ali univerzitetno izobrazbo iz enakega kulturnega okolja, vse so bile v partnerskem odnosu, s povprečnimi osebnimi dohodki in zaposlitvijo. Ravno tako bi bilo smiselno $\mathrm{z}$ vidika zanesljivosti lestvice PAI longitudinalno spremljanje intenzivnosti vezi med nosečnico in plodom skozi celotno nosečnost ter preverjanje napovedne veljavnosti lestvice $\mathrm{z}$ izraženostjo vezi med materjo in novorojenčkom po porodu.

Rezultati naše raziskave predstavljajo pomemben doprinos na področju psihodiagnostičnih sredstev v slovenskem prostoru. Lestvica PAI je psihometrično ustrezen pripomoček za ocenjevanje intenzivnosti vezi med nosečnico in plodom in se lahko uporablja v raziskovalne namene za raziskovanje dejavnikov, povezanih $\mathrm{z}$ razvojem vezi med nosečnico in plodom. Uporabnost lestvice PAI v klinični praksi je zaradi odsotnosti norm ter mejnih vrednosti, na podlagi katerih bi lahko identificirali nosečnice s težavami pri vzpostavljanju vezi s plodom, vprašljiva. Omenjene pomanjkljivosti bi bilo dobro razrešiti v prihodnjih raziskavah.

\section{Literatura}

Barone, L., Lionetti, F. in Dellagiulia, A. (2014). Maternalfetal attachment and its correlates in a sample of Italian women: A study using the Prenatal Attachment Inventory. Journal of Reproductive and Infant Psychology, 32(3), 230-239.

Bielawska-Batorowicz, E. in Siddiqui, A. (2008). A study of prenatal attachment with Swedish and Polish expectant mothers. Journal of Reproductive and Infant Psychology, 26, 373-384.

Bowlby, J. (1982). Attachment and loss: Vol. 1. Attachment. (2nd ed.). New York, NY, ZDA: Basic Books.

Brown, T. A. (2015). Confirmatory factor analysis for applied research. New York, NY, ZDA: The Guilford Press.

Condon, J. T. (1993). The assessment of antenatal emotional attachment: Development of a questionnaire instrument. British Journal of Medical Psychology, 66, 167-183.

Cranley, M. S. (1981). Development of a tool for the measurement of maternal attachment during pregnancy. Nursing Research, 30, 281-284.
Della Vedova, A. M., Dabrassi, F. in Imbasciati, A. (2008). Assessing prenatal attachment in a sample of Italian women. Journal of Reproductive and Infant Psychology, 26(2), 86-98.

Gau, M. L. in Lee, T. Y. (2003). Construct validity of the prenatal attachment inventory: A confirmatory factor analysis approach. The Journal of Nursing Research, 11(3), 177-187.

Hart, R. in McMahon, C. A. (2006). Mood state and psychological adjustment to pregnancy. Archives of Women's Mental Health, 9, 329-337.

Honjo, S., Arai, S., Kaneko, H., Ujiie, T., Muracee, S., Sechijama, H. idr. (2003). Antenatal depression and maternal-foetal attachment. Psychopathology, 36, 304-311.

Hsu, T. L. in Chen, C. H. (2001). Stress and maternal-fetal attachment of pregnant women during their third trimester. The Kaohsiung Journal of Medical Sciences, 17(1), 36-45.

Hu, L. in Bentler, P. M. (1999). Cutoff criteria for fit indexes in covariance structure analysis: Conventional criteria versus new alternatives. Structural Equation Modeling: A Multidisciplinary Journal, 6(1), 1-55.

Jöreskog, K. G. in Sörbom, D. (2006). LISREL 8.80 for Windows [računalniški program]. Lincolnwood, IL, ZDA: Scientific Software International.

Klaus, M. H. in Kennell, J. H. (1976). Maternal-infant bonding. Saint Louis, ZDA: The C.V. Mosby.

Kleinveld, J. H., Timmermans, D. R. M., Van den Berg, M., Van Eijk, J. T. M. in Ten Kate, L. P. (2007). Does offering and performing prenatal screening influence women's attachment to their unborn child? A longitudinal randomized controlled trial. Prenatal Diagnosis, 27, 757-764.

Müller, M. E. (1993). Development of the prenatal attachment inventory. Western Journal of Nursing Research, 15, 199-215.

Müller, M. E. in Ferketich, S. (1993). Factor analysis of the Maternal Fetal Attachment Scale. Nursing Research, 42, 144-147.

Pallant, J. F., Haines, H. M., Hildingsson, I., Cross, M. in Rubertsson, C. (2014). Psychometric evaluation and refinement of the Prenatal Attachment Inventory. Journal of Reproductive and Infant Psychology, 32, 112-125.

Pavše, L., Tul Mandić, N. in Globevnik Velikonja, V. (2017). Vez med nosečnico in njenim nerojenim otrokom. Psihološka obzorja, 26, 1-7.

Raykov, T. (2004). Behavioral scale reliability and measurement invariance evaluation using latent variable modeling. Behavior Therapy, 35(2), 299-331.

Rees, B.L.(1980). Measuring identification with the mothering role. Research in Nursing and Health, 2, 49-56.

Salisbury, A. (2003). Maternal-foetal attachment. Journal of the American Medical Association, 289, 1701.

Siddiqui, A., Hägglöf, B. in Eisemann, M. (1999). An exploration of prenatal attachment in Swedish expectant women. Journal of Reproductive and Infant Psychology, 17, 369-380. 
Sočan, G. (2011). Postopki klasične testne teorije. Ljubljana, Slovenija: Filozofska fakulteta.

Van Bakel, H. J. A., Maas, A. J. B. M., Vreeswijk, C. M. J. M. in Vingerhoets, A. J. J. M. (2013). Pictorial representation of attachment: Measuring the parent-fetus relationship in expectant mothers and fathers. BMC Pregnancy and Childbirth, 13, 138-147.

Van den Bergh, B. in Simons, A. (2009). A review of scales to measure the mother-foetus relationship. Journal of Reproductive and Infant Psychology, 27, 114-126.

Walsh, J. (2010). Definitions matter: If maternal-fetal relationships are not attachment, what are they? Archives of Women's Mental Health, 13, 449-451.

\section{Priloga}

\section{Slovenski prevod Lestvice vezi med nosečnico in plodom (PAI; Müller, 1993)}

Pri vsaki spodnji trditvi označite, kako pogosto se opisana misel, čustvo ali vedenje pojavlja pri vas v zadnjih dveh tednih, pri čemer je 1 = skoraj nikoli, 2 = včasih, 3 = pogosto, 4 = skoraj vedno.

\begin{tabular}{|c|c|c|c|c|c|}
\hline & & $\begin{aligned} \text { Skoraj } \\
\text { nikoli }\end{aligned}$ & Včasih & Pogosto & $\begin{array}{l}\text { Skoraj } \\
\text { vedno }\end{array}$ \\
\hline 1. & Sprašujem se, kakšen je trenutni videz otroka. & 1 & 2 & 3 & 4 \\
\hline 2. & Predstavljam si, da otroka kličem po imenu. & 1 & 2 & 3 & 4 \\
\hline 3. & Prijetno mi je, ko čutim otrokovo premikanje. & 1 & 2 & 3 & 4 \\
\hline 4. & Mislim, da moj otrok že ima osebnost. & 1 & 2 & 3 & 4 \\
\hline 5. & $\begin{array}{l}\text { Drugim osebam dovolim, da položijo dlan na moj trebuh in začutijo } \\
\text { otrokovo premikanje. }\end{array}$ & 1 & 2 & 3 & 4 \\
\hline 6. & Vem, da bo to, kar počnem, pomembno vplivalo na otroka. & 1 & 2 & 3 & 4 \\
\hline 7. & Načrtujem dejavnosti, ki jih bom počela z otrokom. & 1 & 2 & 3 & 4 \\
\hline 8. & Drugim govorim o tem, kaj otrok počne v mojem trebuhu. & 1 & 2 & 3 & 4 \\
\hline 9. & Predstavljam si, katerega dela otrokovega telesa se dotikam. & 1 & 2 & 3 & 4 \\
\hline 10. & Vem, kdaj moj otrok spi. & 1 & 2 & 3 & 4 \\
\hline 11. & Svojega otroka lahko pripravim do premikanja. & 1 & 2 & 3 & 4 \\
\hline 12. & Do otroka čutim ljubezen. & 1 & 2 & 3 & 4 \\
\hline 13. & Kupujem/izdelujem stvari za otroka. & 1 & 2 & 3 & 4 \\
\hline 14. & Skušam si predstavljati, kaj otrok v trebuhu počne. & 1 & 2 & 3 & 4 \\
\hline 15. & Rada sedim tako, da $\mathrm{z}$ rokami objemam trebuh. & 1 & 2 & 3 & 4 \\
\hline 16. & Sanjam o otroku. & 1 & 2 & 3 & 4 \\
\hline 17. & Vem, zakaj se otrok premika. & 1 & 2 & 3 & 4 \\
\hline 18. & Otroka božam preko trebuha. & 1 & 2 & 3 & 4 \\
\hline 19. & Z otrokom delim skrivnosti. & 1 & 2 & 3 & 4 \\
\hline 20. & Vem, da me otrok sliši. & 1 & 2 & 3 & 4 \\
\hline 21. & Ko pomislim na otroka, me prevzamejo močna čustva. & 1 & 2 & 3 & 4 \\
\hline
\end{tabular}

